\title{
Fenomeny czasu fabularnego i przestrzeń we współczesnej literaturze ukraińskiej (na przykładzie prozy Wołodymyra Jaworiwskiego)
}

Elena Dwułyczanska 


\section{Fenomeny czasu fabularnego i przestrzeni we współczesnej literaturze ukraińskiej (na przykładzie prozy Wołodymyra Jaworiwskiego)}

Elena Dwułyczanska

TEKSTY DRUGIE 2017, NR 5, S. 239-245

DOI: $10.18318 /$ td.2017.5.16

$\mathbf{N}$ ie ma wątpliwości, że model światopoglądowy ma silny wpływ na tworzenie się artystycznego obrazu świata czy interpretację znaczenia elementów ideologicznych w kształtowaniu dominant stylu artystycznego współczesnej prozy ukraińskiej. Ciekawa w tym kontekście jest twórczość Wołodymyra Jaworiwskiego jako przedstawiciela najnowszej literatury ukraińskiej.

Badaniem kategorii czasu i przestrzeni zajmowało się wielu literaturoznawców, w tym Michaił Bachtin', Borys Mejłach ${ }^{2} \mathrm{i}$ inni badacze, których elementy te interesowały w twórczości poszczególnych pisarzy.

W Stowniku terminów literackich pod redakcją Romana Hromjaka znajduje się definicja pojęcia chronotop -

1 Zob. М.М. Бахтин Вопрос литературы и эстетики. Исследования разных лет, Художественная литература, Москва 1975. Polskie wydanie: M. Bachtin Problemy literatury i estetyki, Czytelnik, Warszawa 1982.

2 Zob. Б.С. Мейлах Проблема ритму, простору і часу в комплексному вивченні творчості, w: tegoż, Ритм, простір і час в літературі і мистецтві, Наука, Ленинград 1974, s. 4-19.
Elena Arkadiyivna Dwułyczanska doktor filozofii, filolog o specjalności „) Jezyk ukraiński i literatura ukraińska", pracuje w Zakładzie Filologii Ukraińskiej i Komunikacji Społecznej na Ługańskim Uniwersytecie Narodowym im. Tarasa Szewczenki na Ukrainie. Obroniła doktorat w 2012 roku. Autorka ponad 25 artykułów naukowych poświęconych literaturze ukraińskiej i światowej. Uczestniczka konferencji międzynarodowych. Kontakt: dvulichanskaya_|@mail.ru 
„korelacja elementów czasowych i przestrzennych w dziele literackim"3. Właśnie taką integralność i nierozłączność podkreślał Bachtin, zwracając uwagę, że za pomocą chronotopu definiuje się gatunki i różnorodność gatunkową, przy czym pierwszorzędną kategorią jest czas ${ }^{4}$. Podstawowe jest stwierdzenie Jurija Łotmana o tym, że przestrzeń literacka nie jest identyczna z fizyczną (np.geograficzną), chociaż nie może się od niej wyodrębnić. Przestrzeń artystyczna jest modelem świata konkretnego autora ${ }^{5}$.

Istotna dla niniejszych rozważań będzie też myśl literaturoznawcy Borysa Mejłacha:

przedstawienia przestrzenno-czasowe, zachowując swe obiektywne podstawy, stają się nie tylko sposobem przekazywania myśli, uczuć i doświadczeń bohaterów czy autorów, ale służą także jako obrazowa synteza najbardziej skomplikowanych procesów rzeczywistości. Czasoprzestrzeń definiuje artystyczną jedność dzieła literackiego w jego stosunku do prawdziwej rzeczywistości, ${ }^{6}$

akcentując komponent chronotopu w dziele sztuki.

W związku z tym sama definicja cech relacji czasoprzestrzennych umożliwi nam pełniejsze zidentyfikowanie i nakreślenie ideowej orientacji, a także problemu prozy końca XX i początku XXI wieku.

Celem tych badań jest analiza specyfiki płaszczyzn czasoprzestrzennych modeli światopoglądowych w najnowszej ukraińskiej prozie na materiale powieści Wołodymyra Jaworiwskiego.

U podstaw powieści sensacyjneј Варвара серед варварів [Warwara sered warwariw; Barbara pośród barbarzyńców] legło wydarzenie, które stało się nieodzowną cechą egzystencji lat 9o. XX wieku w przestrzeni

3 Літературознавчий словник-довідник, red. Р. Гром'як, Ю. Ковалів і іn., Академія, Київ 2007, s. 714.

4 М.М. Бахтин Вопрос литературы и эстетики.., s. 235.

5 Ю.М. Лотман Проблема художнього простору в прозі Гоголя, w: tegoż Про російську літературу, Мистецтво, Санкт-Петербург 1997 [http://philologos.narod.ru/lotman/gogolspace.htm]. Polskie wydanie: J. Łotman Przestrzeń artystyczna w prozie Gogola, przeł. J. Faryno, w: Semiotyka kultury, wyb. i oprac. E. Janus, M.R. Mayenowa, przedm. S. Żółkiewski, PIW, Warszawa 1977.

6 Б.С. Мейлах Проблема ритму, простору і часу..., Ленинград 1974, s. 6. Tu i dalej przekład tłumaczki [przyp. red.] 
postsowieckiej - wpływy mafii i przestępców. Do epicentrum tych wydarzeń trafiają główni bohaterowie powieści - Warwara i Wartołomej (w opowiadaniu - War) [Barbara i Bartłomiej]. W pogoni za dobrami materialnymi degradują się duchowo, stają się wyobcowani i samotni. Dominantą ideową jest w utworze myśl, że bohaterowie, znajdując się w sytuacji bez wyjścia, otrzymali logiczny rezultat wybranego sposobu życia i rodzaju aktywności. Myśl ta znajduje się w polu szczególnej uwagi autora i łączy się z motywem grzechu.

Fragmentaryczny czas fabularny, uwarunkowany znaczną liczbą retrospekcji, umożliwia skondensowanie czasu akcji do dwóch dni, ale może przy tym zobrazować znaczną część życiowego chronotopu bohaterów. Rzeczywiste warunki początkowe i przyczyny negatywnego stanu rzeczy zostały przedstawione w utworze w formie retrospekcji. Jak twierdzi Nonna Kopystjanska:

niektóre momenty retrospekcji skojarzeniowej mają kluczowe znaczenie w utworze. Skupia się w nich psychologiczna dominanta charakteru bohatera, a przyszła akcja określana jest poprzez przeszłość, podobnie jak zachowanie postaci, ponieważ funkcja retrospekcji asocjacyjnej polega na nieprzywracaniu poszczególnych zdarzeń i przeżyć w pamięci, a ma wywołać wzajemne przenikanie się czasów, które tworzą jedność.

Karą za piękne, dostatnie życie okazuje się to, że Wartołomej kończy uwięziony w zonie $\mathrm{e}^{\mathbf{8}}$, a jego żona z dzieckiem błąkają się po ulicach obcego miasta.

Powieść, jak słusznie zauważa Marija Jakubowska', zbudowana jest na zasadzie kontrastu, który w szczególności przejawia się w relacjach czasoprzestrzennych utworu. Główne płaszczyzny związane z fabułą, Kijów i czarnobylska zona, to dwa diametralnie przeciwstawne światy, które poznajemy również dzięki charakterystyce zamieszkujących je bohaterów. Miasto we współczesnej literaturze, jak słusznie stwierdza Wira Fomenko, jest „encyklopedią” życia społecznego, ,którego paradoks polega na tym, że oferując

7 Н.Х. Копистянська Жанр, жанрова система у просторі тітературознавства, ПАІС, Львів 2005, s. 181.

8 Chodzi o zonę - strefę ochronną wydzieloną wokół Czarnobyla, miejsca katastrofy atomowej [przyp. tłum.].

9 М. Якубовська Твоїм будущим душу я тривожу: Літературний портрет Володимира Яворівського, Тріада-Плюс, Львів 2007, s. 84. 


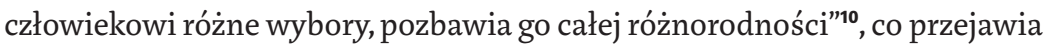
się przede wszystkim w sferze duchowej, w której merkantylizacja i technologia życia prowadzą do utraty potrzeby i impulsu do ciąłego wewnętrznego rozwoju. Przestrzeń stolicy w utworze jest nieprzyjazna, typowo urbanistyczna, jest przestrzenią, w której człowiek czuje się jak pył, co najlepiej oddaje portret Warki. Już samo imię bohaterki (od starogreckiego „cudzoziemiec”) zawiera wskazówkę, że przestrzeń stolicy, w której się ona znajduje, jest dla niej obca, nienaturalna.

Z kolei płynność czasu w powieści uwarunkowana jest społecznie. Retrospekcyjny przebieg wydarzeń zabezpieczonej przeszłości bohaterów okazuje się wartki. A monotonne jest trwanie w materialnych trudnościach i uwięzienie. Nadzieja znalezienia wyjścia z trudnej sytuacji życiowej powoduje dominację motywu ucieczki w opowieści, co przeważnie ucieleśnia postać Warki, która zmieniając jedno locus na drugie, próbuje pozbyć się irytujących myśli z własnej duszy i odnaleźć nowy, prawdziwy sens istnienia. Wielkie ambicje i pragnienie dostatniego życia nie pozwalają na samoidentyfikację Warwary z przestrzenią Tekliwki jako miejscem rodzinnym, co akcentuje oderwanie się bohaterki od swych korzeni, a zarazem jej stopniowy duchowy upadek. W historii tej, w przeciwieństwie do większości dzieł Jaworiwskiego, artystyczna przestrzeń Tekliwki jest implicytna, a wynika głównie z wewnętrznych refleksji Warki, co prowadzi do braku w twórczości pisarza binarnej opozycji wieś - miasto.

Artystyczna czasoprzestrzeń powieści zostaje poszerzona dzięki licznym retrospekcjom Warbary dotyczącym jej podróży do Egiptu, który jako miejsce odpoczynku symbolizuje przestrzeń rozkoszy i przyjemności, a także najczęściej - grzechu. Jednak teraz, stając się miejscem cudzołóstwa głównego bohatera, reprezentuje nową fazę duchowego naporu w codziennym, pełnym życiu, któremu w utworze towarzyszy wiele symboli: róża, pierścień z diamentem, przestrzeń Jerozolimy, rajski ogród, trwałe plamy białego koloru (biały płaszcz, jedwabna biała spódnica, biała batystowa koszula, biała szata, białe sznurki wisiorka) ${ }^{11}$. W zależności od sytuacji i zmian przestrzeni zmienia się także semantyka wymienionych wyżej symboli.

Przeciwieństwem wizerunku Warbary jest Marija, w opowieści reprezentująca przestrzeń czarnobylskiej strefy, której główną populacją są

10 В.Г. Фоменко Урбаністична проза: феномен міста в українській літературі, ДЗ „ЛНу імені Тараса Шевченка”, Луганськ 2012, s. 8.

11 М. Якубовська Твоїм будущим дущу я тривожу.., s. 95. 
przedstawiciele tzw. „dna społecznego”. Kompozycyjne obraz Mariji stanowi odrębną linię fabularną - niby autonomiczna narracja w powieści, która mogłaby stworzyć osobne dzieło ${ }^{12}$. Marija jest rdzenną mieszkanką terytorium, które później stało się strefą zamkniętą. Po utracie w dzieciństwie rodziców, a później - ukochanego chłopca, zabitego przez pijaną zgraję, która zgwałciła Mariję, bohaterka znajduje w sobie psychiczną siłę, aby żyć dalej. Aby pogłębić możliwość zrozumienia osobistej tragedii kobiety, autor tworzy swoistą paralelę między jej losem i okropnymi konsekwencjami tragedii w Czarnobylu, która nie była już w stanie pomnożyć tragedii Mariji. Znajdując się w strefie wśród prawdziwych wilków, Marija pozostaje dobra, ludzka, co przejawia się w dialogu wewnętrznym bohaterki i jej stosunku do otoczenia.

Kontrast płaszczyzn przestrzennych pojawia się w diametralnie przeciwnych obrazach bohaterek. Nie posiadając dóbr materialnych, męża, dzieci, przeżywszy wiele tragedii, Marija w przestrzeni zony okazuje się szczęśliwsza niż Warbara - mieszkanka miasta, która to wszystko ma. Przez co częściowo zneutralizowane zostają dominujące dotychczas w twórczości autora realistyczne zasady obrazowania wpływu otoczenia na człowieka. Jeśli rozwój linii fabularnej powiązanej z Warką jest ogólnie pesymistyczny, to linia Mariji - wręcz przeciwnie, o czym świadczy zmiana ubrania (czysta haftowana koszula, brak gumowych butów) i rower, który pozwala bohaterce wyjechać poza zamkniętą strefę, a zatem - pozostawia czytelnika z nadzieją na godną przyszłość dla cierpiącej kobiety.

Bohaterami podobnymi do Wara są Kostyk i Julko z powieści Кривий танецьь [Krywyj tanec'; Pokrętny taniec]. Śmierć jednego z bohaterów nie nosi w tym utworze znamion tragedii, ale postrzegana jest jako ulga w cierpieniach. Jak pisze Kopystjańska:

człowiek jest częścią przyrody, a zatem istotą podporządkowaną naturalnym biorytmom, zaś jako istota społeczna - rytmom rozwoju społeczno-historycznego. Co więcej, naturalne biorytmy są coraz bardziej niszczone ze względu na podporządkowanie czasoprzestrzeni. Proces ten stał się niestety nieunikniony. ${ }^{13}$

Już sam proces podporządkowywania się rytmowi rozwoju społecznego i historycznego, przy zaniedbaniu sfery duchowej, stanowi główne pole

12

Tamże, s. 85 .

Н.Х. Копистянська Жанр, жанрова система у просторі..., s. 222. 
zainteresowania w wielu dziełach współczesnej literatury ukraińskiej, w tym w prozie Jaworiwskiego. Można odnieść wrażenie, że autor stara się znaleźć odpowiedź na pytanie postawione w XVIII wieku przez Jana Jakuba Rousseau: czy społeczno-historyczny rozwój, cywilizacja, duchowość człowieka rośnie lub maleje $\mathrm{e}^{14}$ ? W taki sposób materialne ubóstwo popycha bohaterów, Kostię i Julka, do kradzieży złomu z wiejskiego cmentarza, do przekroczenia wszelkich norm moralnych, co ostatecznie prowadzi do śmierci Julka.

Koncentrując się przede wszystkim na przestrzeni Tekliwki, autor stara się jak najgłębiej zbadać psychologiczną motywację zachowań współczesnego mieszkańca wsi. Sprzyja temu koncentryczna fabuła opowieści, odsłaniająca podstawowy konflikt utworu: wzajemne relacje samotnego „wyobcowanego" człowieka ze społeczeństwem, któremu nie jest potrzebny. Oddaje to już symbolika tytułu powieści, w którym nawiązano do cytatu z ludowej pieśni: „Krzywy taniec prowadzimy, jego końca nie znajdziemy”, jaki pochodzi ze starej ukraińskiej tradycji zacierania śladów, aby ustrzec swoje życie i dom przed wrogami. Co za tym idzie, ideowo-znaczeniowa orientacja pieśni polegała na odtworzeniu nieskończoności ludzkiego życia i otaczającego świata. Przenosząc ją do współczesności, autor podkreśla ciernistość drogi życia i współczesnych problemów codzienności.

Dominuje w utworze kronikowy chronotop, który odzwierciedla bliski związek i zależność ludzkiej natury od środowiska społecznego. Naprzemienność narracji heterodiegetycznej i homodiegetycznej, wewnętrzne retrospektywne rozważania bohaterów pozwalają ujawnić ich przestrzeń egzystencjalną, śledząc sposoby kształtowania się osobowości.

Locus więzienia, w którym Kostyk i Julko znajdują się każdy w innym czasie i z różnych powodów (Kostia - za wymuszenia na granicy, Julko - za kilka worków z mąką, dzięki którym mógł wyżywić swoją rodzinę, ciężarną żonę), występuje jako klasyczny ośrodek niegodziwości, ohydy i amoralności, reprezentujący niby model współczesnego społeczeństwa.

Zatem bohaterowie współczesnych utworów Jaworiwskiego odczuwają niepewność przyszłości, rozpacz i niepokój, a z tego powodu wydają się pozostawać w - spowodowanym przez los, ale też przez ich czyny - impasie. Specyfika narracyjna i wewnętrzne retrospektywne refleksje bohaterów umożliwiają zanurzenie się w ich przestrzeni egzystencjalnej oraz prześledzenie dróg formowania się charakteru. 
Mimo że fizyczną przestrzeń powieści zaprezentowano wystarczająco różnorodnie, zakres problemów, które starają się rozwiązać bohaterowie, jest dość podobny (brak pieniędzy, bezrobocie, a co za tym idzie stopniowy duchowy upadek i degradacja moralna). Dla czasoprzestrzennej organizacji dzieła charakterystyczna jest zmiana przestrzeni zewnętrznej, co prowadzi do zmian we wnętrzu bohaterów, którzy nie są jednoznacznie pozytywni lub negatywni (Warbara, Wartłomij, Sofija Chrestolubska). Odrębną część czasoprzestrzeni powieści stanowią intymne uczucia i relacje bohaterów. Większy nacisk na nie wynika z ponowoczesnej estetyki i próby oddania współczesnego duchowo-moralnego stanu społeczeństwa, co znajduje się w polu zainteresowań wielu ukraińskich pisarzy.

Przełożyła Iwona Boruszkowska

\section{Abstract}

\section{Elena Dwułyczanska}

UNIVERSITY OF LUHANSK (UKRAINE)

The Phenomena of Fictive Time and Space in Contemporary Ukrainian Literature: The Novels of Volodymyr Yavorivsky

The article analyses the specifics of spacetime planes of ideological models in contemporary Ukrainian prose based on Volodymyr Yavorivsk y's novels. Narrative specificities and the characters' internal retrospective thoughts allow us to immerse ourselves into their existential space and trace their ways of personal development.

\section{Keywords}

spacetime, symbol, art time, space, topos, novel, worldview mode, genre, style, Volodymyr Yavorivsky 